\title{
Emery-Dreifuss Muscular Dystrophy 2, Autosomal Dominant
}

National Cancer Institute

\section{Source}

National Cancer Institute. Emery-Dreifuss Muscular Dystrophy 2, Autosomal Dominant. NCI Thesaurus. Code C126745.

Emery-Dreifuss muscular dystrophy inherited in an autosomal dominant pattern and caused by mutations in the LMNA gene. 